\title{
Phytodiversity Characterization of Mukundara Hills Tiger Reserve
}

\author{
Dharmendra Kumar ${ }^{*}$, P.S. Chauhan, S.B.S. Pandey, Prerak Bhatnagar, \\ M.K. Sharma and Bhuvnesh Nagar
}

Department of Forest Biology and Tree Improvement, College of Horticulture and Forestry, Jhalawar, Agriculture University, Kota-324001 (Rajasthan), India

*Corresponding author

\section{Keywords}

Vegetation,

Density, Basal area,

IVI and D-D curve

Article Info

Accepted:

17 June 2020

Available Online:

10 July 2020

\section{A B S T R A C T}

The present study was carried out for vegetation diversity of Mukundara Hills Tiger Reserve at two sites. In each site, a total of 100 quadrats of $10 \mathrm{~m} \times 10 \mathrm{~m}$ for trees, $3 \mathrm{~m} \times 3 \mathrm{~m}$ for shrubs and $1 \mathrm{~m} \times 1 \mathrm{~m}$ for herbaceous species were randomly laid to vegetation characterization study. There were 36 tree species, 21 shrub species and 56 herbaceous species was recorded. Higher density and basal area of tree stratum was recorded in Site-I (Enclosure) 937 ind. ha ${ }^{-1}$ and $31.87 \mathrm{~m}^{2} \mathrm{ha}^{-1}$ respectively. Higher density and basal area of shrub stratum was recorded in Site-I (Enclosure) 2408 ind. ha ${ }^{-1}$ and $0.5185 \mathrm{~m}^{2} \mathrm{ha}^{-1}$ respectively. In case of herb stratum higher density and basal area was recorded in Site-II (Open) 483000 ind. ha ${ }^{-1}$ and $2824.54 \mathrm{~cm}^{2} \mathrm{ha}^{-1}$ respectively. The value of similarity for tree stratum was $(0.76)$. In case of shrub stratum, similarity was (0.76). In case of herb stratum, similarity was (0.78). Higher species diversity (Shannon wiener index) and higher Simpson's dominance for tree, shrub and herb stratum was 2.60, 2.58, 3.17 and $0.15,0.12,0.0707$ respectively. Two types of dominance diversity curves were also found in this present study in various vegetation stratums.

\section{Introduction}

Phytosociology is the study of the characteristics, classification, relationship, spatial and temporal distribution of plant communities and it is useful to collect such as data to describe the population dynamics of each species studied and how the related to each other species in the same communities (Rao et al., 2015). Tropical dry deciduous forests are rich in economically important species. Dry deciduous forests are known to provide high potential timber revenue (Mahapatra and Tewari 2005). Fire susceptibility during the dry season allows more rapid exploitation and conversion of these forests when compared to evergreen forests. In contrast to tropical rainforests, deciduous forests have received relatively little scientific and political attention, whereas 
degradation and conversion of these forests are of high interest (Gentry et al. 1995). Hadauti plateau of Rajasthan contains variable climatic with diverse flora and fauna. A lot of wild genetic resources are available here. Mukundara Hills National Park can be considered as hot spot in this sense. In order to regulate the exploration and commercial exploitation of bio resources of the area, we must have a comprehensive and up to date list of plants and animals of the region with particular interest to wild cultivars. The wild relatives are the source of natural germplasm for the new and improved varieties via breeding. By considering the importance of all these aspects, the present study aimed to identify the wild relatives of cultivars and their uses by localities.

\section{Topography and climate}

Mukundra Hills Tiger Reserve (MHTR) is named after the two continuous flat topped and almost parallel hills with the narrow central ridges, which are a part of Vindhyan Range system extending from river Chambal to Kalisindh and are approximately $80 \mathrm{~km}$ in length and 3 to $5 \mathrm{~km}$ in width. The general topographic elevation is between $355 \mathrm{~m}$ to $503 \mathrm{~m}$ above mean sea level. The climate of the study site is subtropical, characterized by long and intense hot summer, with low rainfall and short but acute winter. The summer season commences from early March and the heat soon gets intensive in April. The weather is sultry as the rocks get heated during the day, resulting in hot winds, which continue till late in the night. The rainy season commences from late June and continues till September. On an average there are about 39 rainy days and the annual rainfall varies from $600 \mathrm{~mm}$ to $990 \mathrm{~mm}$. The winter commences from November; the coldest months being December-January. A wide variation in temperature is observed round the year, varying from $6^{\circ} \mathrm{C}$ to $45^{\circ} \mathrm{C}$.

\section{Study area}

Mukundara Hills Tiger Reserve is spread across four districts- Kota, Bundi, Chittorgarh and Jhalawar- covering an area of $759.99 \mathrm{sq}$ $\mathrm{km}$. The core area of $417.17 \mathrm{sq}$. $\mathrm{km}$. and a buffer zone covering $342.82 \mathrm{sq} \mathrm{km}$. Mukundara Hills National Park was formerly declared as Darrah Wildlife Sanctuary in 1955. In 2004, the Darrah wildlife sanctuary was declared as a national park with the name Mukundra Hills (Darrah) National Park comprises of three wildlife sanctuaries namely Darrah wildlife sanctuary, Chambal wildlife sanctuary and Jawahar Sagar wildlife sanctuary. In the month of April 2013 government declared it as third Tiger reserve of the state. Darah Sanctuary covers major portion of Mukundara Hills (Vindhyan Mountain Range), so that the National Park named as Mukundara Hills National Park (MHTR). Darrah Sanctuary is situated on National Highway Number-12. The total enclosure area to be built in MTHR is $200 \mathrm{sq}$ $\mathrm{km}$, but $82 \mathrm{sq} \mathrm{km}$ was constructed under phase-I. The total study area of proposed grassland ecosystem is about $200 \mathrm{sq} \mathrm{km}$. It lies between $23^{\circ} 45^{\prime}$ to $25^{\circ} 53^{\prime} \mathrm{N}$ latitudes and $75^{\circ} 9^{\prime}$ to $77^{\circ} 26^{\prime} \mathrm{E}$ longitude of Rajasthan state. According to Champion and Seth, 1968 in Kota forest division lies in group 4 - dry tropical forest.

\section{Materials and Methods}

The field survey and sampling were carried out in the Site-I (Enclosed) and Site-II (Open) falls under Mukundara Hills Tiger Reserve since October 2018 to April, 2019. In every forest site, 100 quadrats of $10 \mathrm{~m} \times 10 \mathrm{~m}$ size were laid randomly to conduct the study of tree species. The tree species includes all the individuals which have $16 \mathrm{~cm}$ or its above girth at breast height, appeared in quadrats. The shrub and herbaceous species were studied by laying 100 quadrats randomly in 
each forest site of study area. In each quadrats, a sub-quadrats of $3 \mathrm{~m} \times 3 \mathrm{~m}$ size for shrubs and a sub-quadrats of $1 \mathrm{~m} \times 1 \mathrm{~m}$ for herbaceous vegetation were selected. The shrub species includes all the individuals which have $5 \mathrm{~cm}$ to $15 \mathrm{~cm}$ collar girth and herbaceous species includes all the individuals which have less than $5 \mathrm{~cm}$ collar girth. Field data were analyzed for abundance, density and frequency. The IVI was calculated fallow standard method. Indices of similarity and dissimilarity were calculated by using formulae given earlier. D-D curves have been used to approach the distribution of relative dominance of species and to interpret the community organization in terms of resource share and niche space. Species diversity and dominance were evaluated by using the following methods. Shannon wiener index and Simpson's index was calculated using importance value index (IVI) of species.

\section{Results and Discussion}

It was inferred from the data that in tree stratum, four species i.e. Annogeissus pendula, Lannea coromandelica, Diospyros melanoxylon and Butea monosperma immersed as a dominant species thereby occurred commonly in both sites i.e. Site-I (Enclosure) and Site-II (Open). In case of shrub stratum, Annogeissus pendula, Lantana camara and Holarrhena antidysenterica are dominant in both sites i.e. Site-I (Enclosure) and Site-II (Open). Flacourtia indica and Butea monosperma are co-dominant in site Site-I (Enclosure) and Site-II (Open) respectively. In case of herb stratum, Aristida adscensionis, Cassia tora and Ocimum basilicum immersed as a dominant in both sites i.e. Site-I (Enclosure) and Site-II (Open), (Table-1, Table 2 and Table-3).

The density of tree stratum was higher (937 ind. ha- ${ }^{1}$ ) in Site-I (Enclosure) and lower (822 ind. ha- $^{1}$ ) in Site-II (Open). The results of present finding are supported by research 583 trees $\mathrm{ha}^{-1}$ in Kalakad-Mundanthurai Tiger Reserve (Ganesh et al. 1996).

The basal area of tree stratum was higher (31.87 $\mathrm{m}^{2} \mathrm{ha}^{-1}$ ) in Site-I (Enclosure) and lower $\left(25.56 \mathrm{~m}^{2} \mathrm{ha}^{-1}\right)$ in Site-II (Open). These basal area values were comparable with the values reported for dry deciduous forest of Baran forest division by $0.90 \mathrm{~m}^{2} \mathrm{ha}^{-1}$ to 8.44 $\mathrm{m}^{2} \mathrm{ha}^{-1}$ (Singh et al. 2018).

In case of shrub stratum, the density was higher (2408 ind. ha ${ }^{-1}$ ) in Site-I (Enclosure) and lower (2328 ind. ha ${ }^{-1}$ ) in Site-II (Open). On the other hand, the basal area was higher $\left(0.5185 \mathrm{~m}^{2} \mathrm{ha}^{-1}\right)$ in Site-I (Enclosure) and lower $\left(0.4448 \mathrm{~m}^{2} \mathrm{ha}^{-1}\right)$ in Site-II (Open). The obtained results are in harmony with the findings by researches (Devilal and Sharma 2010).

The value of similarity for tree stratum 0.76 was observed and in case of shrub stratum, similarity 0.76 and in case of herb stratum, similarity 0.78 (Table-4). This similarity between different Sites may be due to same altitudinal zone and similar type of habitat conditions. Less difference in the value of similarity index indicate that growth forms in the stand responded in a similar fashion (Adhikari et al. 1991). Whereas, minimum similarity observed between different sites may be due to different climatic conditions and different type of habitat. Itow and Nakanishi (1980) reported that large area contained more varied habitat types then smaller ones, and each of the habitat type supports a specific set of its own, which is more or less different from that of other habitat types.

In case of herb stratum, the density was higher (483000 ind. ha $^{-1}$ ) in Site-II (Open) and lower (459100 ind. ha $\left.{ }^{-1}\right)$ in Site-I (Enclosure). 
Table.1 Comparative importance value index (IVI) of tree species in Site-I (Enclosure) and Site-II (Open)

\begin{tabular}{|c|c|c|c|}
\hline \multirow{2}{*}{ S. No. } & \multirow[t]{2}{*}{ Name of species } & \multicolumn{2}{|c|}{ IVI } \\
\hline & & Site-I & Site-II \\
\hline 1 & Acacia catechu & 5.56 & 4.40 \\
\hline 2 & Acacia leucophloea & 6.57 & 4.28 \\
\hline 3 & Acacia nilotica & 1.18 & 3.72 \\
\hline 4 & Aegle marmelos & 7.96 & - \\
\hline 5 & Ailanthus excelsa & 1.74 & 1.84 \\
\hline 6 & Alangium salvifolium & 1.20 & 2.53 \\
\hline 7 & Anogeissus latifolia & 9.82 & 6.70 \\
\hline 8 & Anogeissus pendula & 95.00 & 92.81 \\
\hline 9 & Azadirachta indica & 4.23 & 5.28 \\
\hline 10 & Balanites aegyptiaca & 0.60 & - \\
\hline 11 & Bauhinia variegata & 1.46 & - \\
\hline 12 & Boswellia serrata & 10.78 & 7.56 \\
\hline 13 & Bridelia retusa & 2.33 & 1.40 \\
\hline 14 & Butea monosperma & 20.72 & 53.89 \\
\hline 15 & Cassia fistula & 1.02 & 4.85 \\
\hline 16 & Diospyros melanoxylon & 26.49 & 28.16 \\
\hline 17 & Feronia acidissima & 1.05 & - \\
\hline 18 & Ficus benghalensis & - & 3.03 \\
\hline 19 & Ficus glomerata & 3.45 & - \\
\hline 20 & Ficus religiosa & 2.49 & 4.49 \\
\hline 21 & Flacourtia indica & 4.80 & 2.75 \\
\hline 22 & Gmelina arborea & 1.08 & - \\
\hline 23 & Grewia tilifolia & 1.57 & - \\
\hline 24 & Holoptelea integrifolia & 1.12 & 3.45 \\
\hline 25 & Lannea coromandelica & 41.02 & 32.69 \\
\hline 26 & Madhuca indica & 7.93 & 8.28 \\
\hline 27 & Miliusa tomentosa & 2.64 & - \\
\hline 28 & Mitragyna parviflora & 6.76 & 6.59 \\
\hline 29 & Nyctanthes arbor-tristis & - & 0.63 \\
\hline 30 & Pithecellobium dulce & - & 1.04 \\
\hline 31 & Prosopis juliflora & 5.28 & - \\
\hline 32 & Schleichera oleosa & - & 2.33 \\
\hline 33 & Sterculia urens & 9.76 & 8.36 \\
\hline 34 & Tamarindus indica & 2.67 & 3.67 \\
\hline 35 & Terminalia arjuna & 5.51 & - \\
\hline 36 & Wrightia tinctoria & 6.21 & 5.28 \\
\hline
\end{tabular}

( -) Sign denoted the absence of the species 
Table. 2 Comparative importance value index (IVI) of shrubs/sapling of tree species in Site-I (Enclosure) and Site-II (Open)

\begin{tabular}{|l|l|c|c|}
\hline \multirow{2}{*}{ No. } & Name of species & \multicolumn{2}{|c|}{ IVI } \\
\hline $\mathbf{1}$ & & Site-I & Site-II \\
\hline $\mathbf{2}$ & Acacia catechu & 5.38 & 7.37 \\
\hline $\mathbf{3}$ & Adhatoda vasica & 6.53 & 2.80 \\
\hline $\mathbf{4}$ & Aegle marmelos & 5.41 & - \\
\hline $\mathbf{5}$ & Anogeissus latifolia & 18.26 & 11.70 \\
\hline $\mathbf{6}$ & Anogeissus pendula & 82.64 & 49.98 \\
\hline $\mathbf{7}$ & Butea monosperma & 14.14 & 25.21 \\
\hline $\mathbf{8}$ & Calotropis procera & - & 5.61 \\
\hline $\mathbf{9}$ & Capparis decidua & - & 3.00 \\
\hline $\mathbf{1 0}$ & Capparis sepiaria & 15.16 & 10.52 \\
\hline $\mathbf{1 1}$ & Carissa spinarum & - & 18.07 \\
\hline $\mathbf{1 2}$ & Dichrostachys cinerea & - & 1.98 \\
\hline $\mathbf{1 3}$ & Diospyros melanoxylon & 12.08 & 15.37 \\
\hline $\mathbf{1 4}$ & Flacourtia indica & 23.86 & 13.95 \\
\hline $\mathbf{1 5}$ & Helicteres isora & 4.55 & - \\
\hline $\mathbf{1 6}$ & Holarrhena antidysenterica & 22.64 & 24.59 \\
\hline $\mathbf{1 7}$ & Jatropha curcas & - & 6.38 \\
\hline $\mathbf{1 8}$ & Lannea coromendelica & 8.94 & - \\
\hline $\mathbf{1 9}$ & Lantana camara & 29.65 & 51.30 \\
\hline $\mathbf{2 0}$ & Prosopis juliflora & 20.25 & 20.11 \\
\hline $\mathbf{2 1}$ & Wrightia tinctoria & 7.65 & 11.55 \\
\hline $\mathbf{2}$ Sign & Ziziphus nummularia & 22.85 & 20.48 \\
\hline
\end{tabular}

( -) Sign denoted the absence of the species

Table.3 Comparative importance value index (IVI) of herbs/grasses/seedling of tree species in Site-I (Enclosure) and Site-II (Open)

\begin{tabular}{|r|l|c|c|}
\hline S. No. & Name of species & \multicolumn{2}{|c|}{ IVI } \\
\cline { 3 - 4 } & & Site-I & Site-II \\
\hline $\mathbf{1}$ & Achyranthus aspera & 4.52 & 4.87 \\
\hline $\mathbf{2}$ & Actiniopteris radiata & 0.97 & - \\
\hline $\mathbf{3}$ & Aegle marmelos & 0.67 & - \\
\hline $\mathbf{4}$ & Ailanthus excelsa & - & 0.44 \\
\hline $\mathbf{5}$ & Anogeissus pendula & 1.25 & 1.31 \\
\hline $\mathbf{6}$ & Aristida adscensionis & 50.45 & 44.85 \\
\hline $\mathbf{7}$ & Azadirachta indica & 0.50 & - \\
\hline $\mathbf{8}$ & Barleria prionitis & 3.29 & 3.64 \\
\hline $\mathbf{9}$ & Boechera stricta & - & 0.93 \\
\hline $\mathbf{1 0}$ & Borreria capitata & 1.21 & 1.38 \\
\hline $\mathbf{1 1}$ & Boswellia serrata & 0.69 & 0.92 \\
\hline
\end{tabular}




\begin{tabular}{|c|c|c|c|}
\hline 12 & Brachiaria ramosa & - & 2.23 \\
\hline 13 & Brachiaria reptans & - & 2.13 \\
\hline 14 & Butea monosperma & 1.05 & 1.32 \\
\hline 15 & Cassia tora & 32.47 & 33.58 \\
\hline 16 & Celosia argentea & 4.20 & 3.53 \\
\hline 17 & Cenchrus biflorus & - & 0.80 \\
\hline 18 & Chloris barbata & 13.59 & 12.23 \\
\hline 19 & Chrysopogon fulvus & 3.69 & 2.83 \\
\hline 20 & Commelina benghalensis & - & 1.62 \\
\hline 21 & Corchorus aestuans & - & 2.52 \\
\hline 22 & Cynodon dactylon & 12.02 & 12.64 \\
\hline 23 & Cyperus rotundus & 3.72 & 3.19 \\
\hline 24 & Dactyloctenium aegyptium & 9.58 & 9.20 \\
\hline 25 & Dichanthium annulatum & 10.42 & 8.69 \\
\hline 26 & Diospyros melanoxylon & 0.89 & 1.09 \\
\hline 27 & Echinochloa colona & 9.46 & 9.60 \\
\hline 28 & Elytraria acaulis & 3.31 & 3.42 \\
\hline 29 & Eragrostis aspera & 9.17 & 13.23 \\
\hline 30 & Eragrostis pilosa & 15.15 & 8.12 \\
\hline 31 & Euphorbia hirta & 2.09 & 1.84 \\
\hline 32 & Flacourtia indica & 0.50 & - \\
\hline 33 & Holoptelea integrifolia & - & 1.07 \\
\hline 34 & Imperata cylindrica & 2.70 & - \\
\hline 35 & Lannea coromandelica & 1.18 & 1.34 \\
\hline 36 & Launaea procumbens & 1.81 & 1.81 \\
\hline 37 & Madhuca indica & 0.77 & 0.68 \\
\hline 38 & Martynia annua & - & 0.76 \\
\hline 39 & Merremia emarginata & 0.91 & 0.74 \\
\hline 40 & Ocimum basilicum & 30.44 & 33.83 \\
\hline 41 & Oplismenus burmannii & 2.14 & - \\
\hline 42 & Parthenium hysterophorus & 6.85 & 6.42 \\
\hline 43 & Pedalium murex & 1.27 & 1.61 \\
\hline 44 & Peristrophe paniculata & 6.21 & 6.03 \\
\hline 45 & Physalis angulata & - & 1.16 \\
\hline 46 & Schleichera oleosa & - & 0.59 \\
\hline 47 & Sonchus asper & 1.69 & 1.54 \\
\hline 48 & Tamarindus indica & - & 0.61 \\
\hline 49 & Themeda quadrivalvis & 21.73 & 19.16 \\
\hline 50 & Tribulus terrestris & 1.67 & 2.04 \\
\hline 51 & Tridax procumbens & 5.44 & 5.49 \\
\hline 52 & Triumfetta rhomboidea & 5.28 & 5.00 \\
\hline 53 & Urginea indica & - & 2.13 \\
\hline 54 & Vernonia cinerea & 1.34 & 1.01 \\
\hline 55 & Wrightia tinctoria & 0.91 & - \\
\hline 56 & Xanthium strumarium & 12.80 & 14.84 \\
\hline
\end{tabular}

( -) Sign denoted the absence of the species 
Table.4 Similarity and dissimilarity index of different species in Site-I (Enclosure) and Site-II (Open)

\begin{tabular}{|l|c|c|}
\hline Species & Similarity index & Dissimilarity index \\
\hline Trees & 0.76 & 0.24 \\
\hline Shrubs/sapling of trees & 0.76 & 0.24 \\
\hline Herbs/grasses/ \\
seedling of trees
\end{tabular}

Table.5 Diversity pattern of trees, shrubs and herbs of different plant categories in Site-I (Enclosure) and Site-II (Open)

\begin{tabular}{|l|l|l|l|l|l|}
\hline Species & Sites & $\begin{array}{l}\text { Shannon } \\
\text { wiener index }\end{array}$ & $\begin{array}{l}\text { Simpson's } \\
\text { index }\end{array}$ & $\begin{array}{l}\text { Species } \\
\text { richnes } \\
\text { s }\end{array}$ & $\begin{array}{l}\text { Jacard } \\
\text { index }\end{array}$ \\
\hline \multirow{2}{*}{ Trees } & Site-I & 2.60 & 0.14 & 4.53 & 0.75 \\
\hline \multirow{2}{*}{ Shrubs/sapling of trees } & Site-II & 2.41 & 0.15 & 3.72 & 0.74 \\
\hline \multirow{2}{*}{$\begin{array}{l}\text { Herbs/grasses/seedling of } \\
\text { trees }\end{array}$} & Site-I & 2.44 & 0.12 & 2.34 & 0.88 \\
\hline & Site-II & 2.58 & 0.09 & 2.67 & 0.89 \\
\hline & Site-I & 3.07 & 0.0707 & 4.98 & 0.82 \\
\hline & Site-II & 3.17 & 0.0660 & 5.66 & 0.81 \\
\hline
\end{tabular}

Fig.2 Dominance diversity curve for Site-I (Enclosure) and Site-II (Open) for tree species

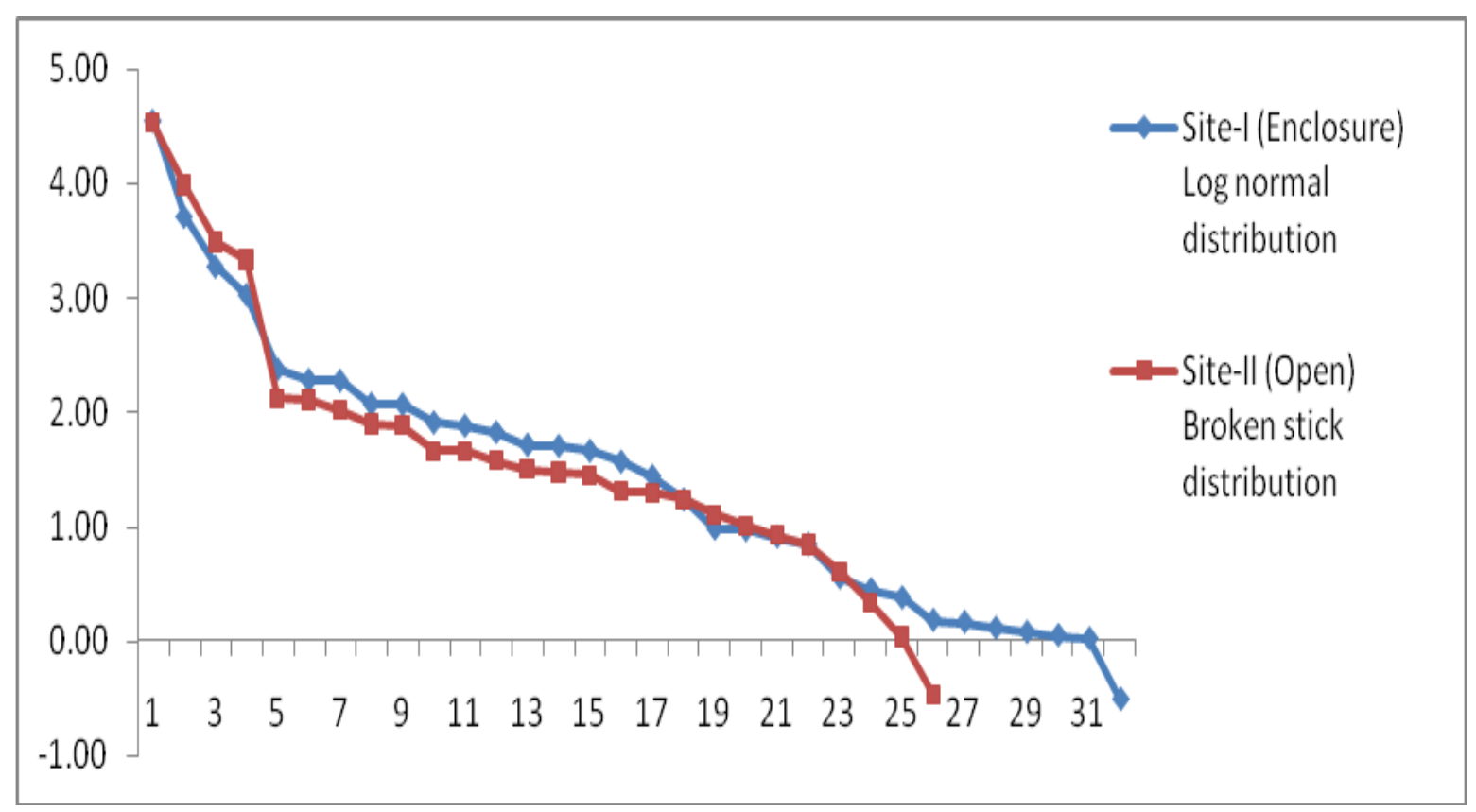


Fig.3 Dominance diversity curve for Site-I (Enclosure) and Site-II (Open) for shrubs/sapling of tree species

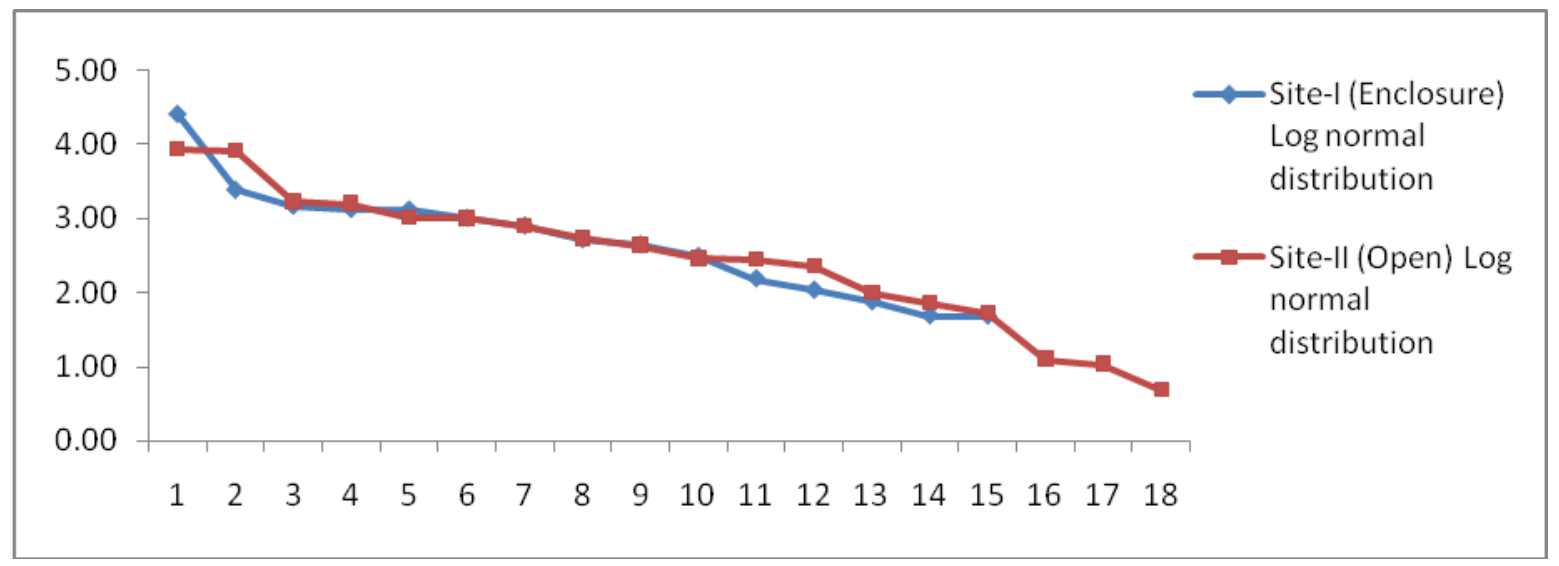

Fig.4 Dominance diversity curve for Site-I (Enclosure) and Site-II (Open) for herbs/grasses/seedling of tree species

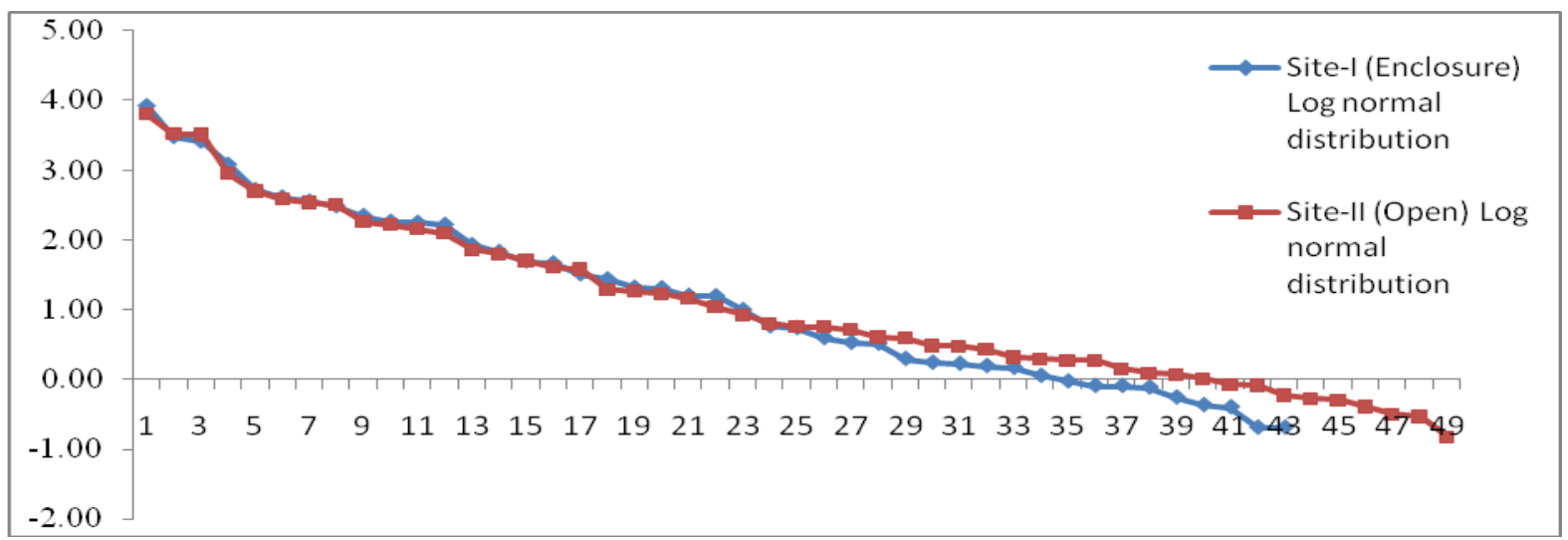

Fig.1 Location map in India and State of the study site

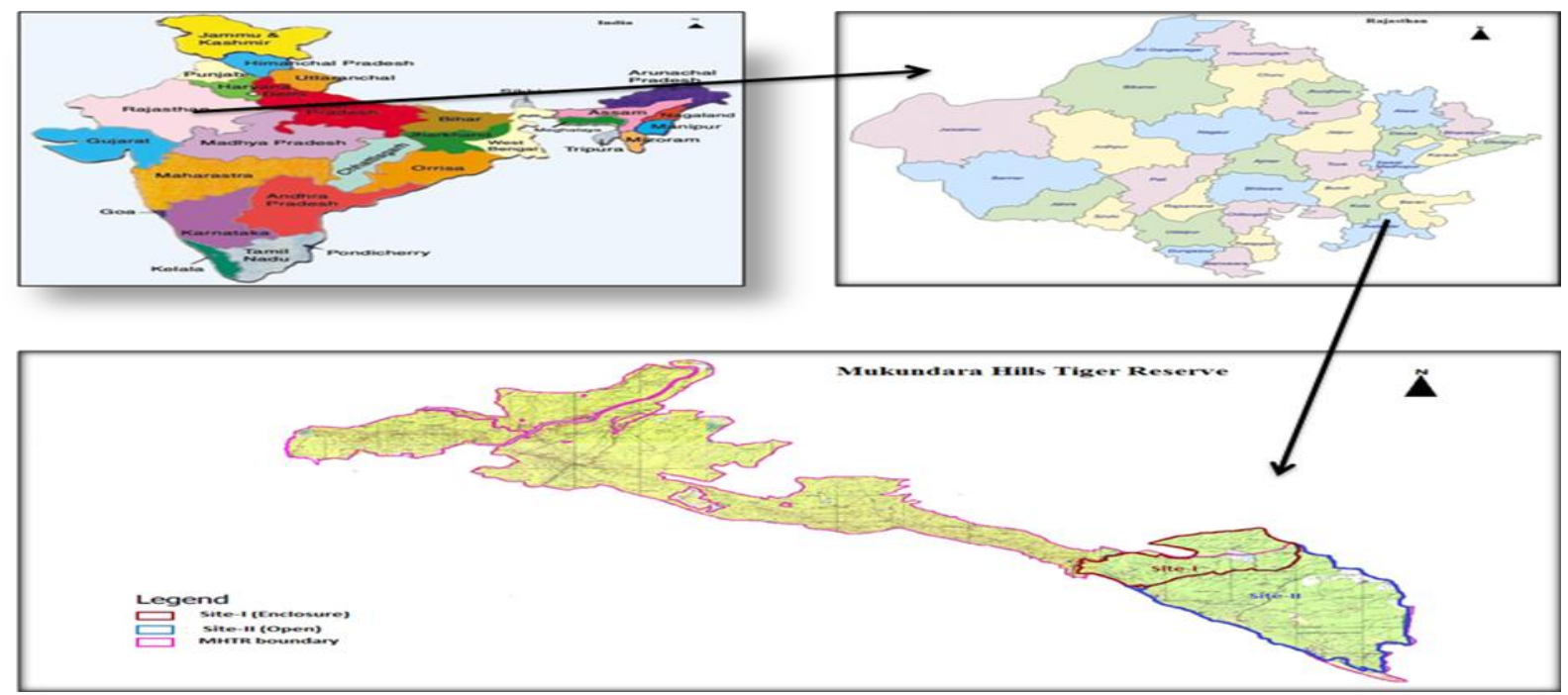


Shannon wiener index of tree stratum was higher (2.60) in Site-I (Enclosure) and lower (2.41) in Site-II (Open). In case of shrub stratum, Shannon wiener index was higher (2.58) in Site-II (Open) and lower (2.44) in Site-I (Open). In herb stratum, Shannon wiener index was higher (3.17) in Site-II (Open) and lower (3.07) in Site-I (Enclosure). The higher Shannon wiener index value 3.17 of herb stratum in Site-II (Open) may be due to less density and open canopy. The lower diversity index (Shannon wiener index) value 3.07 in Site-I (Enclosure) may be attributed to the climax nature of the species with dense cover that might have restricted herbaceous species to germinate and establish. The results of presents finding were supported by researches (Chauhan et al. 2001). This is also well supported by Shannon wiener index reported between 0.78 to 3.45 for forest communities of Garhwal Himalayan by research (Raturi 2012).

The tree stratum dominance (Simpson index) was higher (0.15) in Site-II (Open) and lower (0.14) in Site-I (Enclosure). In case of shrub stratum the dominance (Simpson index) was higher (0.12) in Site-I (Enclosure) and lower (0.09) in Site-II (Open). The herb stratum dominance (Simpson index) was higher (0.0707) in Site-I (Enclosure) and lower (0.0660) in Site-II (Open). The lower concentration of dominance (Simpson index) indicates the sharing of dominance by many species. This is in similarity with the finding of other worker who found concentration of dominance (Simpson index) between 0.10 to 0.99 (Whittaker 1972; Ralhan et al. 1982; Bhadra et al. 2010].

In case of tree stratum, species richness was higher (4.53) in Site-I (Enclosure) and lower (3.72) in Site-II (Open). The shrub stratum, species richness was higher (2.67) in Site-II (Open) and lower (2.34) in Site-I (Enclosure). The herb stratum, species richness was higher (5.66) in Site-II (Open) and lower (4.98) in
Site-I (Enclosure). The results of present findings were in consonance with those reported by researches (Bachulkar and Awale 2010).

In case of tree stratum, Jacard index was higher (0.75) in Site-I (Enclosure) and lower (0.74) in Site-II (Open). The shrub stratum, Jacard index was higher (0.89) in Site-II (Open) and lower (0.88) in Site-I (Enclosure). The herb stratum, Jacard index was higher (0.82) in Site-I (Enclosure) and lower (0.81) in Site-II (Open). The results of present findings were in consonance with those reported by researches (Chauhan et al. 2001).

In case of tree stratum, Site-I (Enclosure) and Site-II (Open) has log normal distribution pattern and broken stick distribution pattern respectively (Fig 2). In case of shrub stratum Site-I (Enclosure) and Site-II (Open) has log normal types of distribution pattern. In herbaceous stratum Site-I (Enclosure) and Site-II (Open) has log normal distribution pattern (Fig 3, and 4).

In conclusion, the present study was carried out in Mukundara Hills Tiger Reserve in Enclosure and Open Site revealed significant difference in vegetation structure, composition, competition, interrelationship and spatial distribution in the entire respective stratum that is tree, shrub and herb.

The voluminous information obtained regarding phytosociological (community analysis), biomass, carbon stock and soil attributes in the present investigation may be used as a baseline information for spatial and temporal studies of similar type of forest and grassland ecosystem structure, composition and community dynamic for further researches. Further the data will be used for scientific management of grassland for sustenance of species, both flora and species for community regulation. 
Finally, the community species need scientific management and locally rare or locally endangered species need holistic conservation for healthy sites and better survival for ecosystem management.

\section{Acknowledgement}

I take this opportunity to express my profound sense of gratitude and indebtedness to my Major Advisor Dr. P. S. Chauhan, Associate Professor \& Head, Department of Forest Biology and Tree Improvment, Advisor Dr. M. K. Sharma, Assistant Professor, Department of Natural Resources Management, Advisor Dr. S. B. S. Pandey, Associate Professor \& Head, Department of Silviculture and Agroforestry. Dr. I. B. Maurya, Dean, College of Horticulture \& Forestry, Jhalarapatan, Jhalawar. We are also thankful to Sh. Ghanshyam Prasad Sharma (Chief Conservator of Forests, Wildlife, Kota), Dr. T. Mohan Raj (Deputy Conservator of Forests, Mukundara National Park, Kota) and Staff members of Mukundara Hills Tiger Reserve and Range Department for their cooperation and moral help.

\section{References}

Adhikari B.S., Rikhari H.C., Rawat Y.S. and Singh S.P. (1991). High altitude forest: composition, diversity and profile structure in a part of Kumaun Himalayan. Tropical Ecology, 32: 8697.

Bachulkar M. and Awale V. (2010). Floristic survey of Sagareshwar wildlife sanctuary, Maharashtra. Indian Forester, 136(12): 1675-1687.

Bhadra A.K., Dhal N.K. and Pattanayak S.K. (2010). Altitude based tree species occurrence in the protected natural forest of Gandhamardan hill ranges, Balangir, Odisha. Boilife, 2(2): 420-421. Chauhan P.S., Manhas R.K. and Negi J.D.S.
(2001). Demographic and Diversity Analysis of tree species in sal (Shorea robusta Gaertn. f.) Forests of Doon Valley. Annals of Forestry, 9(2): 188198.

Devilal R. and Sharma N. (2010). Dominance, diversity and species richness of tree species along an altitudinal gradient of a catchment of Garhwal Himalaya. Indian Forester, 136(7): 943-950.

Ganesh T., Ganesan R., Soubadradevy M., Davidar P. and Bawa K.S. (1996). Assessment of plant biodiversity at a mid-elevation evergreen forest of Kalakad Mudanthurai Tiger reserve, Western Ghats, India. Current Science, 71: 379-392.

Gentry A.H., Bullock S.H., Mooney H.A. and Medina E. (1995). Seasonally dry tropical forests. Diversity and Floristic Composition of Neotropical Dry Forests, 46-194.

Itow S. and Nakanishi K. (1980). Floristic and vegetation diversity of epilithic bryophyte communities insular biography. Japan Journal of Ecology, 30: $45-54$.

Mahapatra A.K. and Tewari D.D. (2005). Importance of non-timber forest products in the economic valuation of dry deciduous forests of India. Forest Policy and Economics, 7(3): 455-467.

Pande P.K., Negi J.D.S. and Sharma S.C. (1996). Plant species diversity and vegetation analysis in moist temperate Himalayan forest. Indian Forester, 126(7): 727-741.

Ralhan P.K., Saxena A.K. and Singh J. S. (1982). Analysis of forest vegetation at an around Naintal in Kumaun Himalayas. Proceedings of the Indian National Science Academy, 48(1): 121137.

Rao D.S., Murthy P.P.and Kumar O.A. 
(2015). Plant biodiversity and phytosociological studies on tree species diversity of Khammam District, Telangana State, India. Journal of Pharmaceutical Sciences and Research, 7(8): 518.

Raturi G.P. (2012). Forest community structure along an altitudinal gradient of district Rudraprayag of Garhwal.
Himalayan Ecologia, 2(3): 76-84. Singh B., Chauhan P.S. and Pandey S.B.S. (2018). Phytodiversity characterization of dry deciduous forest of Baran forest division. Environment and Ecology, 36(2): 361-369.

Whittaker R.H. (1972). Evolution and measurement of species diversity. Taxon, 21(2-3): 213-251.

\section{How to cite this article:}

Dharmendra Kumar, P.S. Chauhan, S.B.S. Pandey, Prerak Bhatnagar, M.K. Sharma and Bhuvnesh Nagar. 2020. Phytodiversity Characterization of Mukundara Hills Tiger Reserve. Int.J.Curr.Microbiol.App.Sci. 9(07): 2037-2047. doi: https://doi.org/10.20546/ijcmas.2020.907.235 